\title{
Rectal fistula due to ovarian teratoma
}

We present a rare case of ovarian teratoma involving both the rectum and the urinary bladder.

A 23-year-old woman presented with lower abdominal pain for 5 years, passing hairs in her stools for 18 months, and passing hairs in her urine and increased frequency of micturition for 4 months. On clinical examination, no mass was palpable. Abdominal ultrasound revealed a left adnexal echogenic lesion involving the urinary bladder. Examination of the urine revealed pus cells.

A computed tomography (CT) scan of the abdomen showed a $4.0 \times 5.6 \times 4.2-\mathrm{cm}$, illdefined mass with specks of calcification that was protruding into the bladder cavity through its left posterior wall ( $\bullet$ Fig. 1). The mass also had air specks within it and was adherent to the rectosigmoid colon, as shown by loss of the fat plane. Colonoscopy showed a growth that had a tuft of hair protruding into the lumen at $15 \mathrm{~cm}$ from the anal verge (๑ Fig. 2).

Intraoperative findings included a $5 \times 4 \times$ $3.5-\mathrm{cm}$ left ovarian mass that was invading the urinary bladder anteriorly and the rectosigmoid colon posteriorly. A left ovarian teratoma was excised ( $\bullet$ Fig. 3 ). The defects in the urinary bladder and colon were closed primarily. Histopathology of the resected specimen revealed a mature ovarian teratoma. The patient has been followed up regularly for the last 6 months.

Complications of ovarian dermoids include torsion (16\%), rupture $(1 \%-4 \%)$, malignant transformation $(1 \%-2 \%)$, infection ( $1 \%)$, and invasion into adjacent viscera $(<1 \%)$ [1]. The bladder and rectum are the organs most commonly involved when spontaneous rupture into adjacent viscera occurs [2-4]. Patients with rupture of a dermoid cyst into the bladder may present with complaints such as pilimiction (passage of hair in the urine) or passage of other material from the dermoid cyst [5].

The formation of fistulas with the urinary bladder and the rectum in the same patient is a very rare complication of ovarian dermoid cysts. To the best of our knowledge, such a case has not been previously reported.

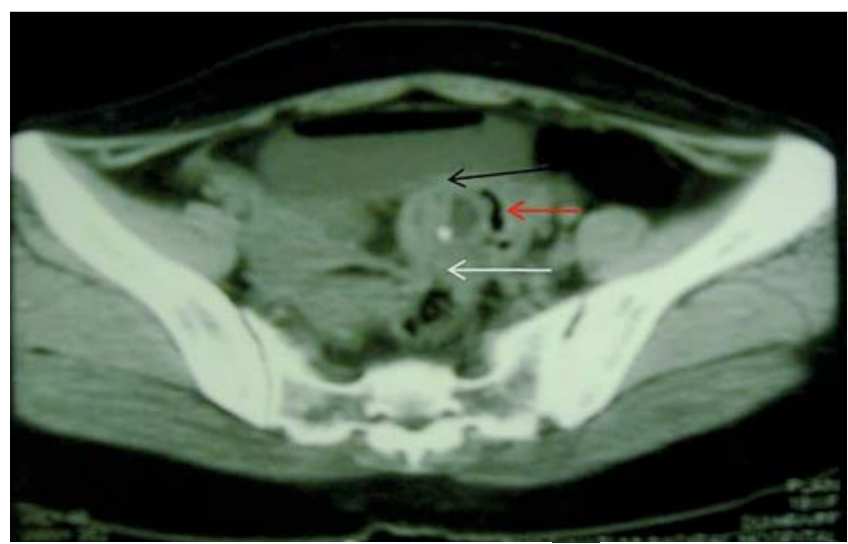

Fig. 1 A computed tomography $(\mathrm{CT})$ scan in a 23-year-old woman with a long history of abdominal pain showing a left adnexal mass with air specks (red arrow) that was involving the left posterior wall of the urinary bladder (black arrow) and the wall of the rectosigmoid colon (white arrow).



Fig. 2 Colonoscopic view of the lesion found $15 \mathrm{~cm}$ from the anal verge that had a tuft of hair (black arrow) protruding into the rectum.

\section{Endoscopy_UCTN_Code_CCL_1AD_2AG}

\section{Competing interests: None}

\section{R. Singh ${ }^{1}$, S. Joshi ${ }^{1}$, H. Hatimi ${ }^{1}$, P. Somani ${ }^{2}$, P. Rath ${ }^{2}$, R. M. Joshi ${ }^{1}$}

${ }^{1}$ Department of General Surgery, T N Medical College \& B Y L Nair Ch Hospital, Mumbai, India

2 Department of Medical Gastroenterology, T N Medical College \& B Y L Nair Ch Hospital, Mumbai

\section{References}

1 Park SB, Kim JK, Kim KR et al. Imaging findings of complications and unusual manifestations of ovarian teratomas. Radiographics 2008; 28: 969-983

2 Tabata K, Nagakura K, Hirano I et al. A case of fistula between the urinary bladder and an ovarian dermoid cyst. Hinyokika Kiyo 2004; 50: 219-221

3 Farkouh E, Allard M, Paquin JG. Benign solid teratoma of the ovary with rupture into the rectum. Can J Surg 1982; 25: 77-78

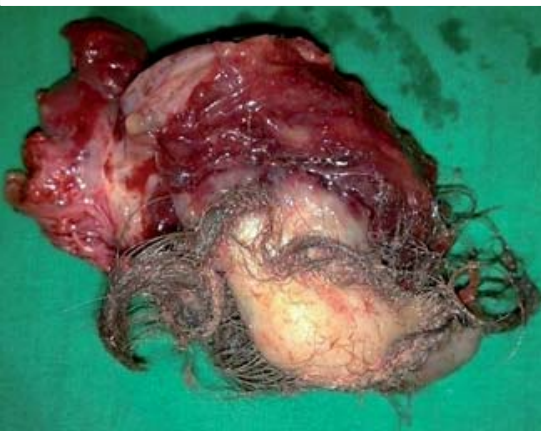

Fig. 3 Macroscopic appearance of the resected specimen showing the hair on the surface of the lesion consistent with the diagnosis of an ovarian teratoma.

4 Cebesoy FB, Baskonus I, Mete A et al. Benign ovarian dermoid cyst complicated with rectal fistula formation: an unusual case. Arch Gynecol Obstet 2009; 279: 179-181

5 Bhuiyan ZH, Akhter N, Islam MF et al. Pilimiction. Mymensingh Med J 2008; 17: $107-$ 110

Bibliography

Dol http://dx.doi.org/

10.1055/s-0032-1309394

Endoscopy 2012; 44: E260

(c) Georg Thieme Verlag KC

Stuttgart · New York ISSN 0013-726X

\section{Corresponding author}

\section{R. Singh, DNB}

101-B Cosmos Apartments

$3 r d$ Cross Lane

Lokhandwala Complex

Andheri W

Mumbai 400053

India

Fax: +91-22-23072663

drrajinder@gmail.com 